\title{
Konvergentnost vjere i razuma u svjetlu heteroafirmativnosti enciklike Fides et ratio
}

\author{
Marko Vučetić*
}

\begin{abstract}
Sažetak
U članku se propituje filozofijski aspekt izgradnje kršćanskog humanizma sadržanog u enciklici Fides et ratio. Analizom odnosa autonomije filozofije i teologije izgraduje se platforma da se sinteza vjere i razuma ne gleda u svjetlu hermetizma, nego sukladno zakonitosti autentičnosti. Autentična filozofija ne može postati teologijom, baš kao što ni autentična teologija ne može postati filozofijom. Načelom heteroafirmativnosti ostvaruje se sinteza vjere i razuma na način da se istina oslobodi formalističkog i od čovjeka otuđenog oblika stvarnosti. Egzistencijalno je relevantna istina ona koja ne isključuje, koja ima snažne integrativne mehanizme te tako pridonosi osmišljavanju ljudskog života.

Ključne riječi: filozofija, teologija, vjera, razum, egzistencija
\end{abstract}

\section{Uvod}

Problem konvergentnosti razuma i vjere dijelom je svediv, iako ne u potpunosti, na problem konvergentnosti filozofije i teologije (naime, teologija sadržava razumnost koja je teologijska, baš kao i filozofija vjeru koja je filozofijska). ${ }^{1} \mathrm{Na}-$ vedeni problem prisutan je u od samog susreta kršćanske misli i grčke filozofije, koja je pokušala pronaći metafizički oslonac razumijevanja složenog odnosa svijeta i božanske stvarnosti. Razumljivo je da se iz tog susreta ostvaruje plodan dijalog, ali i posreduju mnoga pitanja kojima na vidjelo dolazi egzistencijalni karakter kršćanske istine i metafizičke filozofske spekulacije. Kroz čitavo srednjovjekovno razdoblje ostaje, na različite načine formulirano, prisutno uvjerenje

* Doc. dr. sc. Marko Vučetić, Odjel za filozofiju Sveučilišta u Zadru. Adresa: Obala kralja Petra Krešimira IV. br. 2, Zadar, Hrvatska. E-pošta: mvucetic@unizd.hr

1 Za razumijevanje ovog rada potrebno je uzeti u obzir temeljno polazište da, u filozofijskom smislu, enciklika Fides et ratio pretpostavlja fenomenologiju distingviranja znanja o bitima, kao apodiktičkih datosti, od činjenica. Sinteza je moguća (čak i nužna) na razini činjeničnosti i egzistencijalnog vitalizma (zato se, u fenomenologiji Karola Wojtyłe, osoba promatra kao ona koja se u činu otkriva te je, stoga, čin neodvojiv od osobe na način da osoba jest osoba-čin), a nije moguća na razini fenomena koji ostaju u svijesti, odnosno na razini korelata, modusa i eidetskih biti (filozofija ostaje filozofijom, razum razumom, teologija teologijom, a vjera vjerom). 
kako između filozofije i teologije, odnosno između vjere i razuma vlada sklad ili neprotuslovlje. No, nastupanjem moderne misli, osobito od Descartesa naovamo, naglasak više nije stavljen na sintezu vjere i razuma, nego na neprevladivu autonomiju vjere u odnosu na razum, kao i, posljedično, razuma u odnosu na vjeru.

Ivan Pavao II. izdaje, nakon Lava XIII. i enciklike Aeterni patris, drugi po redu crkveni dokument, encikliku Fides et ratio, koju u potpunosti posvećuje odnosu vjere i razuma. Aeterni patris dijagnosticira stanje, poziva na ponovnu uspostavu skolastičkog načela o suglasju vjere i razuma, a Fides et ratio upravo je filozofija i teologija prožimanja vjere razumom i razuma vjerom. Bez prožimanja razuma vjerom dolazi do krize razuma kako u filozofiji, tako i u teologiji. Naime, autonomija filozofijske istine ili filozofijskog razuma, očituje se u radikalnom nepovjerenju prema moći razuma da spozna konačne i apsolutne istine, odnosno u nepovjerenju prema mogućnosti zahvaćanja izvaniskustvene stvarnosti. Autonomija teologije u odnosu na filozofiju, dovodi do rasta različitih oblika unutarteološkog racionalizma, kojega enciklika Fides et ratio vidi u paleti različitih formi fideizama — sve do racionalističkog biblicizma. ${ }^{2}$

\section{Ontološko i epistemološko predrazumijevanje odnosa enciklika Aeterni patris $i$ Fides et ratio}

Enciklika Fides et ratio svoje značenje crpi u povijesno-filozofijskom i filozofijsko-teologijskom kontekstu krize razuma u teologiji, ${ }^{3}$ kao krize razuma i krize teologije, kako je to apostrofirano i u enciklici Aeterni patris. Povijesno-filozofijski i filozofijsko-teologijski odnos tih enciklika stoga zasigurno nije odnos uzroka i posljedice, ali ni odnos svih mogućih derivata proizišlih iz susljednosti vremenski usporedivih datosti. Enciklika Aeterni patris uočava opasnost ako se svjetlo vjere nekritički predimenzionira i odvoji od svjetla razuma, jer razum (filozofija), ukoliko je pravilno usmjeren (vođen ljubavlju prema istini) vodi prema istini vjere (AP 4). Nadalje, taj odnos nije odnos naravnog rasta, u smislu da će ono što razum spozna kao praeambula fidei nužno ili spontano voditi prema vjeri, nego odnos razumskog utemeljenja vjerske istine, shvaćen na dvostruk način: prvotno se, iz same naravi, ${ }^{4}$ propitujući njezine granice otvara prostor za dimenziju vjere

2 Taj je oblik radikalne autonomije svojevrstan oblik autonomije monističkog tipa dijaloškog depotenciranja. Heteroafirmativnost nije utemeljena na negaciji drugoga, nego na priznanju vlastitosti drugoga te se, stoga, autonomija filozofije i teologije u enciklici Fides et ratio ostvaruje pod dijaloškim vidom progresije stvarnosti.

3 Razum i teologija nisu u odnosu heterogenih izvora, u smislu da bi razum teologiji instrumentalno pripadao, posredstvom filozofije. M. Seckler zato ističe: »No razum na teologiju ne utječe samo putem filozofije nego i neposredno. Filozofija i filozofski razum jesu instancije izvan teologije « (Seckler, 2005, 92).

4 Taj odnos čovjeka i ostalih bića koja mu se postavljaju, u odnosu na njega samoga, kao ne-ja istražuje fenomenologija. Upućenost čovjeka na svijet izgrađuje plauzibilnu osnovu za transcendentalnu fenomenologiju i argumentaciju u prilog primordijalne združenosti čovjeka i svijeta (Heidegger, 1988, 56) ili, naprotiv, za nužnost filozofijskog razotkrivanja bitnih struktura odnosa 
i vjerske istine kao one koja nije u koliziji s razumskim zahtjevima. Nadalje, kada se ostvari čin suglasja vjere i razuma, ta istina suglasja, ${ }^{5}$ kao filozofsko-teološka istina, izriče se filozofskim konceptima kao istina kojom se dijalogizira s ostalim, od istine vjere izuzetih filozofija, filozofskih sustava ili filozofema. Ideal uspješne filozofsko-teološke suradnje u funkciji istine papa vidi u djelu Tome Akvinskoga, koji je znao razlikovati vjeru od razuma, cijeniti njihovo dostojanstvo u koje je uključeno dostojanstvo istine, a ono ne može biti ostvareno ni hermetizmom vjere ni hermetizmom razumske istine (AP 18). Lav XIII. izražava žaljenje što je unutar kršćanske misli došlo do udaljavanja od Tomine filozofije, kao i od njezinih načela, što je, posljedično, vodilo prema eklekticizmu, fideizmu i svim drugim oblicima apsolutiziranja partikularne istine. Kešina, sintetizirajući moguće razloge poticanja ponovnog oživljavanja Tomine filozofije, izdvaja najvažnije: »protivnici Crkve vjeru napadaju na planu (području) razuma, važno je da se na istom planu dadu odgovori; postoji velika opasnost da obitelj i društvo budu izloženi zarazi krivih (lažnih) mišljenja « (Kešina, 2001, 223). Za razliku od 19. stoljeća, u suvremenosti kriva mišljenja svijetom pronose rahitično uvjerenje da se sveukupnost naših osjetilnih iskustva promatra kao formu (ili forme) istine, a taj reduktivni pristup stvarnosti Ivan Pavao II. naziva prividom autonomije ljudskog (FR 80). Naime, potraga za iskustvenim u iskustvenom svijetu pogoduje nastanku ničim opravdanog osjećaja kako je upravo taj svijet u sebi dostatan, da je oduvijek onoga što uopće može biti. Sebenastalošću svijeta na više ili manje raciomorfan način utemeljuje se povlašten status autonomije mudrosti svijeta koja počiva na postulatima nepotrebnosti postavljanja pitanja, kako o metafizičkom uzroku nastale stvarnosti cjeline svijeta, tako i o nužnosti isključenja pitanja o Bogu. No, tu valja odmah uočiti kako je sam govor o nedostatnosti, nepotrebnosti, zaboravu metafizičkog ili spekulativnog u sebi samom već jedan oblik metafizičnosti i spekulativnosti. Naime, spekulativno se nešto govori o stvarnosti metafizičkog reda. Kako bilo, čovjek je nedvojbeno biće koje progovara, istražuje o apsolutnoj stvarnosti. ${ }^{6}$ Ivan Pavao II. duboko je svjestan svih dimenzija metafizike autonomije ljudskoga, koja najprije negira Boga, potom samu metafiziku, a u konačnici i samog čovjeka. Njezina antropološka struktura je struktura pobunjenosti, ona potom neizostavno generira i transgenerira pobunjenost na sva područja ljudske aktivnosti, osim na područje autonomije ljudskoga. Stanje u suvremenoj misli,

čovjeka i svijeta kao njegova neprekoračivog horizonta (Merleau-Ponty, 1978, 5). Smatramo da se heteroafirmativnost enciklike Fides et ratio iščitava upravo u otvorenosti prema fenomenološkoj metodi kao nosivoj filozofskoj osnovi kojom Ivan Pavao II. prepoznaje egzistencijalnu važnost tomizma i veritativnost vjere.

5 Istina suglasja je istina koja proizlazi iz bitka bića, ona nije kružna i ne potiče ideju ontološkog, egzistencijalnog i epistemološkog parcijalizma (Fabro, 1988, 432).

6 Kao umsko biće po svojoj naravi, čovjek neizostavno postavlja najdublja metafizička pitanja. »Čovjek je bitstvom svojim umsko živo (animal rationale). Ukoliko se ovo živo ne dekoncentrira, tj. ne rasprši i izgubi u bezbitnosti gotovo beskonačnih mogućnosti promašivanja svoje životnosti, nego se sabere, koncentrira, usredotoči u svome bitstvu, ono se odnosi spram sebe sama te istodobno, kroz taj sebeodnos, spram umskosti (rationalitas), 'umljivosti' (rationabilitas) svega što jest i može biti« (Despot, 2008, 742). 
prvenstveno filozofskoj, uvelike odgovara, u teološkom kontekstu, sljepilu oholosti praroditelja, koji su se ontološki i epistemološki samopostavili. Tu samopostavljenost, kao vid slabe ontologije i epistemologije, razbija Kristov dolazak i njegovo djelovanje. Autonomija sljepila oholosti razbija se dakle puninom Božje objave u Isusu Kristu otvarajući put povjerenja u zrelost ljudskog razuma i njegovih mogućnosti. ${ }^{7}$ Naime, autonomija sljepila oholosti pred ljudsku slobodu postavlja ograničenja proizišla iz centrifugalnih silnica iskustvenog, lišenog integrirajuće dimenzije. Odvajanje čovjeka od Boga generira odvajanjem razuma od slobode, istine od čovjeka, čina od subjekta, odnosno generira egzistencijalnom deautorizacijom ili destrukcijom jastva. Gubitak integrirajućih mehanizama, na teološkom području, očituje se u tzv. pročišćavanju teologije od filozofije, čime se ujedno podržava temeljna postavka pozitivnih znanosti kako je područje teologije, objave i vjere izvan razuma (u smislu ne-razuma), a potom je potrebno učiniti još samo malen korak u smjeru suprotstavljanja teologije razumskomu (teologija kao antropologija porobljavanja ljudskog). Filozofija, pak, lišena integrirajućeg oslonca, ostaje bez svog materijalnog objekta istraživanja — ona, naime, više ne može reflektirati o svoj stvarnosti (aktualnoj i potencijalnoj), nego ili razlaže, na sintetski način, rezultate do kojih su došle ostale znanosti, ili stvara ideološki okvir podržavanja različitih autonomija centrifugalnih silnica partikularnog, kao što je to, primjerice, u postmodernoj misli u formi opiranja metanarativima. Konačno, pozitivna znanost na sebe preuzima teret integrirajućeg mehanizma, kojemu nipošto nije dorasla jer tada prelazi metodološki horizont formalnog i materijalnog ograničenja, pa se obilno služi uporabom univerzalnih kvantifikatora, stvarajući privid kako se sve unutar nečega odnosi na sve svega što jest. No, valja naglasiti da se od prigovora metanaracije i iracionalnosti teološkog govora teologija neće obraniti ako racionalizira vjeru i njezin sadržaj prevede u oživotvorenje logičkih pravila, načela i aksiomatskih formi na način da se egzistencijalno bogatstvo i rješenje enigme ljudskog postojanja, koje je u Bibliji izraženo metaforičkim jezikom, sada demetaforizira i aksiomatizira. Ako bi se to dogodilo, a u hermetizmu suvremenog transtemporalnog tomizma nastanilo se upravo takvo htijenje, ${ }^{8}$ racionalizirana vjera postala bi sve osim vjere, a ljudska sloboda otuđila

7 Bez povezanosti s vjerom, razum ostaje bez izazova nadilaženja sebe i zato »istinska filozofija bitka pretpostavlja njezinu povezanost s teologijom, tj. zahtijeva jedinstvo razuma i vjere, dakako, uz poštivanje njihove legitimne autonomije« (Devčić, 2000, 98).

8 Pod transtemopralnim tomizmom mislimo na ona nastojanja koja Tominu filozofiju uzdižu na razinu metapovijesne važnosti u smislu da se takva misaonost odvaja od povijesne dimenzije kako bi stekla privid istine za sva vremena. Takva filozofija prestala bi biti filozofijom jer bi postala skupom kategoričkih istina koja umjesto upitnosti i potrebe za dijalogom uspostavlja vrijednosni sud o autorima i njihovu djelu. Jedan takav predstavnik transtemporalnog tomizma bio bi J. Maritain i njegovo djelo Tri reformatora (Maritain, 1995), iako bi, da i sami ne upadnemo u zamke transtemporalnosti i donošenja vrijednosnih sudova o autorima i njihovim djelima, isti Maritain u svojim ostalim, manje polemičkim i motivacijski desubjektiviziranim djelima, bio predstavnik egzistencijalnog tomizma. Heteroafirmativni pristup vodio bi odvajanju transtemopralnog od egzistencijalnog, pokazujući kako egzistencijalno pripada filozofiji, a transtemporalnost — neovisno je li riječ o pojedinom iskazu, skupu iskaza ili djelu — ne pripada ni filozofiji ni vremenu kao temeljnomu obilježju ljudske egzistencije. 
bi se iz egzistencijalne sfere i svela na razinu jezične stvarnosti ili iskaza o slobodi odnosno iskaza o vjeri koju neizostavno prate iskazi o zabludama drugih. ${ }^{9}$

\section{Dijalektika stvarnosti i iskaza o stvarnosti}

Ako čovjek ostane u posjedu partikularne istine kao istine slobode, vrši se izravan udar na njegovu narav, jer mu se oduzima sloboda kao stvarnost i supstituira se iskazom o stvarnosti slobode. ${ }^{10}$ No, upozorava Ivan Pavao II.: »Čovjek po svojoj naravi istražuje istinu. To istraživanje nije osuđeno samo na postizanje djelomičnih istina koje ovise o događajima ili znanostima; čovjek ne traži samo istinsko dobro za svoje pojedine naume. Njegovo istraživanje upravljeno je prema daljnjoj istini koja može rasvijetliti smisao života« (FR 33). Nedostatna ili manjkava upotreba slobode stoga utječe na našu sposobnost priznavanja istine, ali je, isto tako, kao što ispravno primjećuje Rossi »potrebno mnogo više $\mathrm{u}$ ispravljanju ljudske destruktivne prakse od pukog priznavanja intelektualne greške« (Rossi, 2017, 4). Tu valja uočiti egzistencijalno-antropološki karakter istine, jer upravo na toj dimenziji istine svoju fizionomiju određuju i dominantne ideologije i misaoni pravci 19. stoljeća: materijalizam, pozitivizam, ateizam i evolucionizam. ${ }^{11}$ U Fides et ratio uočava se da se ideološke dominacije nadvladavaju modelom usklađenosti razuma i vjere kojim se fundira metodološki obrazac spekulativnog istraživanja pod vidom neprotuslovnosti istine razuma istini vjere. ${ }^{12}$ Kako se u jednom i u drugom slučaju radi o istini koja je neodvojiva od ljudskog bića, jer proizlazi iz ljudske biti (razumske i religijske), u istraživanju je potrebno naglasak staviti na ontološki karakter, da bi se potom pokazala i egzistencijalno-antropološka dimenzija te istine. Čovjek naprosto ima potrebu spoznati istinu i na nju osloniti čitavu svoju egzistenciju. Pitanja o smislu i svrsi postojanja nameću se u različitim formama, iako se diferenciraju u ovisnosti o stupnju naobrazbe, tradicije i kulture u kojoj se čovjek nalazi, no ona se, na sadržajnoj razini, pretjerano ne razlikuju. Ljudska egzistencija je „uvremenjena“ te, kao takva, izručena jednokratnosti vremenski zamjetljivog manifestiranja:

9 Heteroafirmativnost tražitelja istine vodi u smjeru onoga što nalazimo kao temeljno obilježje filozofije, a ono je vitalitet razuma koji se očituje u ljubavi prema istini (Maritain, 1981, 12).

10 Odnos slobode i iskaza o slobodi može se promatrati u analogiji s odnosom jednog čovjeka i mnogih ljudi. Čovjek koji je slobodan, slobodan je kao jedan, ali i kao mnogi. Istina slobode ne ovisi o broju niti se zbrajanjem umanjuje jer »zbroj ljudi ne čini čovjeka i čovječanstvo ništa manje ljudskim nego što to pojedinac već jest« (Rahner, 2007, 469).

11 U 19. se stoljeću Katolička crkva našla pred mnogim izazovima. Povijesno promatrano, to je vrijeme kada se »razvija historijsko-kritička povijesna znanost, nastaje moderna filologija, rastače se dotadašnji javni poredak, kršćanski obilježen feudalni sustav; proklamiraju se ljudska prava, zagovara se suverenost i autonomija moderne države i dr. Time se podiže cijeli val kritike postojeće crkvene tradicije, njezina samo po sebi razumljivog stanja predaje i zahtjeva za mjestom u javnom životu « (Hünermann, 2008, 725).

12 Na temelju neprotuslovlja istine vjere istini razuma, Maritain je argumentirao opravdanost kršćanske filozofije. Filozofija je po svojoj naravi jedna, ali su, stvarno i povijesno, mnoga njezina stanja — pa tako i kršćansko — u ljudskom subjektu (Maritain, 1978). 
ima početak, već kad jest, i nužnost prestanka, zato što jest u vremenu. Ivan Pavao II. ističe sljedeće: »Nitko ne može izbjeći ova pitanja, ni filozof ni običan čovjek. Od odgovora koji se na njih daju ovisi najvažniji dio istraživanja: može li se dogoditi da se dopre do sveopće i apsolutne istine, ili ne? «(FR 27). Dakle, sama narav egzistencijalne istine, da bi bila i ostala autentična, ne dopušta zatvaranje u subjektivnost, odnosno u oživotvorenje Kierkegaardova određenja istosti istine i vjere kao subjektivnosti. ${ }^{13}$ Prostor unutar kojeg će se sveopća istina osloboditi, ili to neće, pripada isključivo onim područjima ljudskog istraživanja koja stvari ne sagledavaju na subjektivan način, koja su sposobna reflektirati o prvim i posljednjim uzrocima bića, a to su, u korpusu usustavljenih znanja, jedino teologija i filozofija. ${ }^{14}$

No, i te dvije paradigmatike znanstvenog znanja razlikuju implicitnu od eksplicitne spekulacije. Jedna i druga otpočinju s osjećajem epistemološke udivljenosti što čovjeka preplavljuje kada počinje razmišljati o sebi u svijetu. Implicitna spekulacija izgrađuje, uvjetno rečeno, metodologiju spontaniteta zadržavanja osjećaja udivljenosti, a eksplicitna se spekulacija svojim konceptualnim aparatom udaljuje od osjećaja, objašnjava ga i tako trajno napušta njegov spontanitet. Kriza mišljenja nastaje u onom trenutku kada struktura spontaniteta preuzme pseudokonceptualno ruho, neovisno je li tada riječ o govoru o apsolutnom biću i konačnoj vrednoti koja tendira u smjeru filozofije ili teologije. Jednoznačno rečeno, kriza u koju zalazi teološka i filozofska misao kriza je odsutnosti sustavnosti, ali i kriza sustavnosti onkraj realnog iskustva. Naime, baš kao što osjećaj umije izgraditi metodologiju spontaniteta, tako i um može izgraditi sustavnost o nečemu što nema realni, nego idealni bitak, a tada umjesto metodologije spontaniteta imamo metodologiju podvojenosti na „pravu“ ili umsku stvarnost i iskustvenu ili „slabu“ stvarnost. Na polju filozofije i teologije to se očituje kroz pretjerano povjerenje u moći uma ili, pak, nekritičko nepovjerenje. I jedno i drugo vodi do produbljivanja krize antropologije u teologiji i filozofiji. Ivan Pavao II. nudi smjernice koje jasno govore o statusu filozofije u teologiji, odnosno ulozi razuma u promišljanju sadržaja vjere, a one glase: »Crkva, sa svoje strane, ne može učiniti drugo negoli visoko cijeniti posao razuma, kako bi dospjela do onih odluka koje sam ljudski život čine časnijim. Ona sama, naime, u filozofiji opaža put kojim se spoznaju glavne istine koje se tiču ljudskoga života. Istodobno filozofiju drži nužnim oruđem pomoću kojega bi razum dublje istražio vjeru i istina se evanđelja podijelila onima koji je još nisu upoznali« (FR 5). Tim je smjernicama pozicionirana uloga filozofije u ljudskom životu, da bi potom bio uspostavljen uravnotežen odnos između filozofije, koja čovjeka dovodi do temeljnih istina, i teologije, koja polazi od objavom posredovanih temeljnih istina.

13 Istost stine i vjere, odnosno istine kao subjektivnosti koja se suočava s objektivnom nesigurnošću samorizika, opisan je u Kierkegaarodovu djelu Strah i drhtanje (Kierkegaard, 2000).

14 N. Ančić naglašava potrebu uspostave dijaloga teologije s filozofijom, zbog općedruštvenih potreba. »Osim unutarcrkvenih razloga postoje i neki aktualni društveni čimbenici koji osobito nameću hitnu potrebu dijaloga oko posljednjih istina o čovjeku, a on je nemoguć bez poznavanja filozofskog mišljenja« (Ančić, 2008, 751). 
Ivančić iznosi objekciju kako neki autori upućuju prigovor da enciklika Fides et ratio nedovoljno razlikuje um od razuma. Naime, Possenti, upozorava Ivančić, smatra kako je »nesporazum nastao pogrješnim prevođenjem grčkih pojmova 'logos' i 'nous' « te, nastavlja, »na mjesto razuma i pod značenje razuma došao je um koji je u prijevodu poprimio sadržaj razuma« (Ivančić, 2008, 762). Distinkcija između razuma i uma, dakle, distinkcija je između intuitivnog zahvaćanja - to je aktivnost koja je navlastita duhovnim ili humanističkim znanostima — i diskurzivnosti koja je više vezana uz prirodne znanosti. Kako bilo, tu nije dovoljno jasno uspostavljena distinkcija, jer i ona, smatramo, proizlazi iz modela spontaniteta i taj model podržava. Aktivnost moći uma ne počiva na snazi intuitivnog zahvata, nego na evidenciji. Filozofija na koju se enciklika poziva ona je filozofija čiji je značaj prepoznat u enciklici Aeterni patris. Kontinuitet između tih enciklika kontinuitet je uočavanja krize suvremenog svijeta, koja je moralna, religiozna, duhovna itd., ali je prvenstveno kriza antropološke istine. ${ }^{15}$ Filozofija, baveći se temeljnim istinama ljudskog života, nadvladava krizu u kojoj se našla uslijed filozofijskog opterećenja metodologijski posredovanog obrasca jednokratnosti istine, na što se potom nadovezuje relativizam, skepticizam i nihilizam u svoj lepezi njihovih izvedenica (Hünerman, 2008, 732). Tako, primjerice, pozitivističke i strukturalističke filozofije počivaju na postavci kako filozofija, uslijed razvoja prirodnih znanosti, ostaje bez vlastitog predmeta istraživanja, što za posljedicu ima nerazumijevanje temeljnih pitanja ljudskog života, koja su daleko izvan dohvata takvih filozofija. Macan upozorava: »Dokle god se nije dao odgovor na fundamentalna pitanja, sva kultura ostaje ispod mogućnosti refleksije ljudskog duha. A ne može se u svemu pribjegavati ni samo svjetlu Objave, jer program 'fides quaerens intellectum' nije izgubio ništa od svoje aktualnosti« (Macan, 2000, 36). Fundamentalna pitanja jesu egzistencijalno-antropološka, ali ih se nikakvom filozofijsko-egzistencijalnom metodom ne može ni formulirati, a nekmoli naseliti konačnim odgovorom. Egzistencijalna metoda, shvaćena u širem smislu riječi kao metoda svega individualnog, ${ }^{16}$ stvara svoju kulturu koja je podložna hermetizmu individualnog. Naime, tada je svaki problem, problem individualne dimenzije - individualno se postavlja, individualno rješava $i$, isto tako, individualno provjerava i uspoređuje s nekim drugim susljednim slijedom dinamike individualnog unutar kulture hermetizma. Antropologije koje se začinju unutar takve kulture i same postaju antropologijama individualnog,,${ }^{17}$ što se osobito oči-

15 U tom kontekstu zanimljiva je Rahnerova eksplikacija individualne i egzistencijalne norme. Govor moralne univerzalnosti odvija se u kontekstualnom okviru individualne egzistencijalne situacije (Rahner, 1963, 217-134).

16 Kada je riječ o individualitetu ljudske vrste, tada valja pri prosudbi zbiljno uzeti da se ljudska egzistencija razlikuje od masivnosti stvorenog bitka, baš kao i od Božjeg bitka. K. Rahner apostrofira sljedeće: »Konkretiziranje čovjeka događa se s Božjim stvaranjem i sebepriopćenjem, sa stvorenjskom radikalnom različitošću od Boga i s distancom spram njega kao apsolutne svete Tajne i ujedno u njegovoj milosnoj apsolutnoj blizini« (Rahner, 2007, 212).

17 Filozofije individualnog negiraju metafizička načela, ali i moral. Time je u filozofiji i pozitivnim znanostima »ljudska osoba izgubila središnje mjesto u takvom istraživanju, a na njezino mjesto je došao tehnološki napredak koji sve više poprima ulogu poganskog demijurga «(Dadić, 2000, 392). 
tuje u stvaranju novih pojmova i pridavanja novih značenja postojećim pojmovima, a sve s ciljem pokušaja utemeljenja adekvatne distinkcije između mnogih individualnih stvarnosti. Teologija na taj izazov ne smije odgovoriti hermetizmom objave, što je u izravnoj suprotnosti s naravi objave, jer njome Istina ulazi u vrijeme i povijest (FR 11). Hermetizam individualnog ugrađivao bi se u strukture podržavanja kozmičkog modela, a hermetizam bi objave vodio u smjeru strukture formiranja kulture fideizma, a, valja priznati, ni jedna ni druga krajnost ne dotiču fundamentalna ljudska pitanja na koja se može dati odgovor isključivo spekulacijom i refleksijom. Stoga filozofijska i teologijska spekulacija ne idu nauštrb egzistencijalne istine, nego omogućavaju uočavanje komplementarnosti filozofijskog i teologijskog pristupa jednoj apsolutnoj istini, ujedno shvaćajući ograničenja ili zastranjenja, odnosno krize u koju ulaze i filozofija i teologija ako ostanu bez integrirajućih elemenata konvergiranja apsolutnoj istini. U tom kontekstu valja tumačiti odnos objave i filozofije u enciklici Fides et ratio, jer: »Ova istina koju nam Bog objavljuje u Isusu Kristu, ni najmanje se ne protivi istinama koje se stječu pomoću filozofije. Dapače, dva stupnja spoznaje vode do punine istine« (FR 34). Iako se ta enciklika ponekad pokušava razumjeti u koordinatama koegzistencije $^{18}$ filozofije i teologije, tomu nije tako. Naime, ukoliko na koegzistenciju primijenimo zakon neproturječnosti, isključenja trećeg i identiteta, entiteti koji egzistiraju (promatrano „u sebi“ entiteta) ničim nisu pozvani da njihova koegzistencija (kolekcija egzistencija entiteta „u sebi“‘) konvergira prema zajedničkoj, apsolutnoj istini. Nadalje, koegzistencija ima smisla, održiva je i unutar jednog raznorodnog teleološkog sustava. Tako, primjerice, danas koegzistiraju različite istine o smislu cjeline ljudskog roda. Pozitivna znanost, kada nešto govori o posljednjoj stvarnosti, neizostavno filozofira i teologizira, čime prekoračuje svoje granice, ali ne i granice koegzistencije jer ujedno upućuje zahtjev teologiji i filozofiji čime bi se to one trebale baviti ako žele ostati u horizontu korisnosti, osobito korisnosti koegzistencije shvaćene na način postulata pozitivne znanosti. Takvo mišljenje je neodređeno, referira se isključivo na cjelinu postavljene istine imanencije koegzistirajućeg horizonta. Antropologija čina, zahvaljujući unutarnjemu potencijalu fenomenološke analize iskustva, shvaća da istina nije konstrukt u funkciji održavanja modaliteta neodređenosti koegzistiranja.

18 Koegzistencija naime ne predmnijeva propitivanje ontološkog statusa onoga koji ili onoga što egzistira u svijetu ostalih egzistirajućih entiteta. Tim pojmom se — kao što je tijekom rada nekoliko puta naglašeno, a sada se daje osnaženo značenje — ističe samo puka činjenica zajedničke prisutnosti izvan ništavila bitka. Jezikom postmoderne misli, koegzistiraju različiti narativi, a ontološki je status metanarativa (teološki govor) izvan i protiv koegzistencije. No, ako se koegzistencija poima u smislu konvergencije, onda teologija i filozofija konvergiraju, jer jezikom egzistentnog bitka progovaraju o apsolutnoj istini. 


\section{Mišljenje smisla i neodređenost mišljenja}

Ivan Pavao II. nadvladavanje neodređenosti mišljenja (dakle, mišljenja koje tek mišljenjem treba mišljenje postati, jer to nije, ničemu ne pripada) vidi u aplikaciji tzv. „krize smisla“ na takva neodređena mišljenja, a sve s ciljem uočavanja, temeljem dvostruke negacije (ne-određenosti i sadržajne besmislenosti mišljena hranjenog krizom smisla), kako se istinski napredak svih formi i razina ljudskog mišljenja ostvaruje u priznavanju nepovredivosti i osobitosti, $\mathrm{u}$ formalnom i materijalnom smislu, različitih mišljenja. Time se ne propagira partikularnost i načelo egalitarnosti, nego se, na primjeru odnosa teologije i filozofije, pokazuje važnost posljednje ili apsolutne istine, koja je sadržana u objavi Boga ljudima, osobito u punini objave u Isusu Kristu. ${ }^{19}$ Konvergentnost različitih znanja, ako se ona upare s teleološkom neophodnošću, otvara prostor za aktualiziranjem filozofijskog znanja kao mudrosnog — smislu otvorenog i na smisao upućujećeg. Time se naprosto želi reći kako filozofija nije pozitivna znanost niti služi isključivo u funkciji pozitivnih znanosti — bilo da propituje njihove granice, bilo da se promatra kao kritička sinteza rezultata pozitivnih znanosti. Filozofija nije povijest znanosti, niti je reducirana na znanstvenu filozofiju znanosti. Ona će, ako ostane vjerna svojoj naravi, pa i dalje ostane ljubiteljica mudrosti, sva mišljenja iz svih mogućih područja mislivosti, osvijetliti svjetlom vrijednosti i smisla te tako učiniti evidentnim da sva znanja vode prema jednomu, konačnomu smislu i konačnomu cilju. Time se, putem filozofije, sve znanosti i sva znanja, pa i same filozofske istine, otvaraju prema teologiji koja počiva na Božjoj objavi. ${ }^{20}$ Razlog je sljedeći: »Riječ Božja otkriva posljednju svrhu čovjeka i daje opći smisao njegovim pothvatima na zemlji. Zbog toga ona poziva filozofiju da se posveti pronalaženju naravnoga temelja tom smislu, a to je religiozna ustrojenost svakoga čovjeka« (FR 81). Autonomija filozofije nije autonomija od istine. Upravo na toj postavci papa vrednuje doprinos filozofije u humanizaciji koja se ne može izvršiti odbijanjem tematiziranja smisla. Jednim takvim odbijanjem započinje bolno odvajanje filozofije od teologije, praćeno nemogućnošću spoznaje značaja metafizičke, religiozne i antropološke istine. Naime, antropologija, metafizika, religija, a osobito teologija, daju odgovor na pitanje temeljne istine o čovjeku, a taj odgovor je upravo odgovor smisla. ${ }^{21} \mathrm{U}$ suvremenoj misli, poglavito idealističkoj i

19 Objava u Isusu Kristu punina je ljudske i Božje objave u kojoj »ne postoji ljudski strah, nema nikakvih nagodbi da bi se stvorilo povoljne uvjete za prihvaćanje, nema diplomacije koja bi sporednim putovima postigla ono što se ne može postići redovnim putem« (Balthasar, 2012, 396).

20 Kada teologija, filozofija i znanost ne bi bile upućene jedna na drugu, došlo bi ili do endogenog rasta znanja ili do njegovog petrificiranja. J. Ratzinger tu opasnost slikovito predočava idejom parka prirode te zaključuje: »Očito je da se ljude ne može jednostavno proglasiti nekom vrstom religijsko-povijesnoga i kulturalno-povijesnoga parka prirode, rezervata u koji ne smije prodrijeti novi vijek« (Ratzinger, 2004, 67).

21 Smisao ljudskog svijeta određen je metafizičkim Ništa, Božjom objavom koja ništi metafizičko Ništa stavljajući čovjeka pred Riječ te, konačno, sposobnošću urastanja u tradiciju ljudskog pamćenja. Rahner problematizira zaborav zaborava dajući mu snažnu antropološku obojanost jer u zaboravu još uvijek biva čovjekom, a u zaboravu zaborava odbacuje ljudskost, jer: »Samo 
racionalističkoj, ${ }^{22}$ autonomija razuma shvaćena je jednostrano na način da se filozofiju u potpunosti odvaja od religijske istine, što za posljedicu, na području filozofije, ima prebacivanje težišta s postavljanja metafizičkih pitanja na spoznajne probleme, a potom osobito na problem granica, mogućnosti i uvjeta spoznaje. To odvajanje teologije od filozofije, na teološkom planu, rezultira nastankom otvorenog, ali i skrivenog fideizma. ${ }^{23}$ Otvoreni fideizam je eksplicitnog karaktera, a skriveni fideizam ima mnoge forme, kao što je primjerice sljedeća: »Drugi oblici skrivenog fideizma mogu se prepoznati po tome što se spekulativna teologija malo cijeni, a isto se tako preziru izlaže i klasična filozofija « (FR, 55). Filozofija i teologija, kada ih se oslobodi smisla i upućenosti jedne na drugu, sve više počinju sumnjati u spoznajne mogućnosti i sposobnosti uma te dovode do antropološke krize. Tim se odvajanjem produbljuje kriza teologije i filozofije u tolikoj mjeri da dolazi do onoga što Devčić zove, fragmentiranjem znanja (Devčić, 2000, 93). Fragmentiranjem znanja čovjek živi onkraj smisla života, zadovoljava ga puka informacija i jednokratnost rješavanja problema, što u konačnici dovodi do instrumentalizacije uma jer je u potpunosti podređen rješavanju nekog partikularnog problema. Instrumentalizacija uma, dakle, događa se u onom trenutku kada um preuzima funkcionalnu ulogu: dolazak do rješenja upravo tog problema. Instrumentalizacija teologije događa se tada kada u teologiji nema mjesta za filozofiju, jer bez filozofske osnove utemeljenja nadnaravnog smisla teologija doživljava metamorfozu iz logičkog i logoičkog u fideističko nijekanje razumskog. Naravno, time se ne zagovara identitetnost teološkog s filozofskim, nego se u realističkim filozofijama prepoznaje osnova za razumijevanje onoga što teologija ima reći. Objavljena istina i istina umom dohvatljiva odnose se kao nadnaravna i naravna stvarnost. Otvorenost prema nužnom smislu u redu naravne stvarnosti filozofija prepoznaje kao, samoj naravnoj stvarnosti, transcendentnu razinu, a ta je za red naravne stvarnosti transcendentna razina istine, kada se propituje po zakonitostima teološke spekulacije, samoj teologiji imanentna stvarnost. Jednoznačno rečeno, kriza teologije kriza je teološke spekulacije ili odricanje od filozofije kao takve, ${ }^{24}$ odnosno neprihvaćanje realistične filozofije, neovisno je li riječ o realističnoj fenomenologiji, epistemologiji ili, pak, metafizici.

možemo kazati da je čovjek onda čovjek kada to živo biće razmišljajući, u riječi i u slobodi dovodi pred sebe i u pitanje cjelinu svijeta i opstojanja, makar on pritom bespomoćno zamukne pred tim jednim i totalnim pitanjem « (Rahner, 2007, 76).

22 Fabro također u svojim djelima čini otklon od idealističke i racionalističke filozofije jer u njima nestaje istinski pojedinac i sloboda izbora. Pojedinac nije subjekt izbora, on je izabran u igri zakona koji djeluju u svijetu i stvaraju povijest (Fabro, 2004, 175).

23 Fideizam dijelom nastaje kao posljedica pogrešnog poimanja unutarbiblijske racionalizacije. Ona, naime, kako to primjećuje Otto, nije racionalizacija nauštrb numinoznoga, naprotiv: »U Isusovu Evanđelju dovršilo se stremljenje prema racionalizaciji, moralizaciji i očovječenju ideje Boga što je bilo živo od najstarijih vremena predaje starog Izraela, osobito u proroka i u psalmima, pa je i numinozno ovdje bivalo sve bogatije prožeto predikatima bistrih i dubokih racionalnih vrijednosti ćutilne duše «(Otto, 2006, 115).

24 Kriza teologije i kriza filozofije nastaju, smatra Ratzinger, kao posljedica autonomiziranja razuma od svakog povijesnog iskustva. Filozofija se tada zatvara u nesposobnost izlaska iz unutarnje istine uma. Teologija, naprotiv, tada ostaje bez epistemološkog oslonca, stoga se uistinu može 
Ako povučemo paralelu s enciklikom Aeterni patris, uviđamo kako je već Lav XIII. uočio opasnost nedostatne teološko-filozofske izobrazbe tadašnjih svećeničkih kandidata, koji nisu mogli obraniti teološke istine, ali niti uspostaviti komunikaciju, na argumentativno-informativnoj razini, s tadašnjim mislećim svijetom koji je snažno bio pod utjecajem filozofijske moderne. Hünermann takvo uspavano i redundantno stanje u Crkvi naziva aporijskim jer se s modernom Crkva suočava s time »da se filozofsko mišljenje i oblikovanje javnog života toliko promijenilo da je Crkva sa svojom dosadašnjom samorazumljivošću i sa svojim samorazumijevanjem u tomu dalekosežno marginalizirana « (Hünermann, 2008, 726). Smatramo da tu nije riječ o nečemu „dosadašnjem“, jer iz same naravi „dosadašnjeg“ — dakle nečega što traje oduvijek ili neodređeno, gotovo tradicijskog podrijetla - nipošto ne može pronaći model „drugačijosti“ u odnosu na „dosadašnjost", a to Lav XIII. upravo čini: poziva na kršćansku tradiciju sinteze filozofsko-teološkog mišljenja unutar koje je um transcendirao sebe sama slobodom, ujedno otvarajući i potičući razvoj, jezikom diferencijacije govoreći, i razumske stvarnosti - dakle, one stvarnosti koju je potrebno objasniti (spaciotemporalna razina), a ne razumjeti (razina bitka). Ivan Pavao II. svoj program uspostavljanja kulture istine, koja također počiva na sintezi filozofije i teologije, fundira i razlaže na sljedeći način: »Pošto se ove stvari razmotre, primjereni odnos koji treba uspostaviti između teologije i filozofije imat će oblik svojevrsnoga kružnog napredovanja. Početak i prvotni izvor teologije je riječ Božja objavljena u povijesti, dok će krajnji cilj nužno biti razumijevanje te riječi koje se polako i razgovijetno opaža, već kako naraštaji jedan za drugim slijede« (FR 73). Kriza teologije, započeta modernom, također je i kriza filozofije, jer se i sama filozofija odmaknula od istine do koje se dolazi umom i slobodom. Rješenje Ivana Pavla II., iako u svojem formalnom obliku pripada filozofsko-teološkoj metodi Tome Akvinskoga, uistinu je epohalno, jer se filozofiju čuva od krize slobode, koju počesto gubi u modernoj i suvremenoj misli ateističkog humanizma, naime, dovodi je se u vezu svojevrsne tenzije s teološkom istinom razumijevanja objavljene riječi Božje, što joj jamči slobodu istraživanja unutar istine (sačuvana joj je veritativnost). Nadalje, sama teologija, zahvaljujući odnosu tenzije (riječ je o autonomiji teologije u odnosu na filozofiju, što je svakako stanovita tenzija) s filozofijom, ostaje na liniji življene, razumljene istine koja, čak i u globaliziranom svijetu, ima unutarnji kapacitet iz kojeg može i mora nastati kultura koja govori u prilog integrirajućeg antropološkog mehanizma sinteze vjere i razuma. Kršćanski humanizam sintezi vjere i razuma ne pristupa selektivno, naprotiv, jača njihove mehanizme autentičnosti kako bi se omogućilo da ljudska egzistencija ostane onaj povlašteni topos humaniteta sposoban za interioriziranje zakonitosti heteroafirmativnosti kršćanskog humanizma.

izvući valjan zaključak kako: »Nevolja filozofije, to jest nevolja u koju se pozitivistički fiksiran razum umanevrirao, postala je nevoljom naše vjere « (Ratzinger, 2004, 122). 


\section{Zaključak}

Konvergentnost vjere (teologije) i razuma (filozofije) u svjetlu heteroafirmativnosti kršćanskog humanizma ostvaruje se, dakle, onkraj načela autonomije i hermetizma. Teologija je autonomna u odnosu na filozofiju, baš kao što je filozofija autonomna u odnosu na teologiju, ali među njima ne vlada odnos isključivosti. Enciklika Fides et ratio na najbolji mogući način — aktualizacijom intencije pomirenja filozofije i teologije u misaonom prostoru suvremenosti — pokazuje kako se filozofija i teologija, kao dvije znanstvene discipline koje obilježava radikalnost upita spoznaje totaliteta svijeta i apsolutne istine, kao i posredovanje normativnih načela i kriterija prosudbe, nalaze u poziciji usmjerenosti prema mudrosti — a mudrost je, još od antičkih vremena određena kao spoznaja svijeta pod vidom istine. Teološka istina stoga je razumska, teologiji razum ne dolazi posredstvom filozofije, nego je razum već uključen u teološku spekulaciju, a budući da je tako, ni vjera, kao antropološki analogijski korelat teologiji, ne može preuzeti militantan ili isključiv stav prema razumu. O odnosu filozofije i teologije stoga se ne može govoriti u kategorijama instrumentalnosti ili funkcionalnosti, nego jedino u smislu konvergentnosti. Teologija je, zahvaljujući neodvojivomu razumskomu sadržaju, usmjerena na odnos konvergentnosti prema filozofiji, jer i filozofija sadržava svoju, u odnosu na teologiju, autonomnu razumsku dimenziju. Upravo iz autonomije razumskog teološkog i razumskog filozofskog filozofija i teologija nalaze se u trajnom dijaloškom odnosu sinteze vjere i razuma u teologiji i sinteze razuma i vjere u filozofiji. Naime, razumski govor o naravnom i razumski govor o nadnaravnom nipošto ne mogu biti u odnosu suprotstavljanja i međusobnog isključenja. Istina, suvremena kultura, u kojoj dominira kriterij autonomije ljudskoga (od pragmatizma do nihilizma), negativno se odnosi kako prema mogućnosti odnosa filozofije i teologije, tako i prema mogućnosti razuma da spozna istinu. No, kultura autonomije ljudskoga ne promiče kulturu ljudskog dostojanstva, nego epidemiju nepovjerenja i traženja sigurnosti u raznoraznim oblicima hermetizma. Enciklika Fides et ratio Ivana Pavla II. u sebi pomiruje dvije naizgled nepomirljive ideje - ideju kontinuiteta s kršćanskom misaonom tradicijom (u nju je uključena i tradicija kršćanske filozofije) s idejom dijaloga sa svom religijskom (religioznom) i sa svom razumskom stvarnošću. Ako bismo željeli postaviti kriterij sinteze vjere i razuma i konvergentnosti filozofije i teologije, nedvojbeno bi to bila punina Božje objave u Isusu Kristu. Filozofija do toga ne može doći, no, do toga, valja priznati, ne dolazi ni teologija. Ona od toga polazi. Ta istina je objavljena, a ne teologijskim umom kreirana. Dakle, s objavljenom istinom teologija dolazi k filozofiji, istina vjere prilazi u susret istini uma i obogaćuje ga mogućnošću (nipošto militantnom nužnošću) novih uvida o konačnoj istini. Teologija koja nije u stanju izreći tu istinu nije teologija objavljene istine, nego derivat autonomije ljudskoga kao neuspjeli derivat autonomije božanske stvarnosti. Filozofija koja nije u stanju susresti se s objavljenom istinom nije filozofija potrage za istinom, nego filozofija hermetizma partikularne istine koja nije u stanju razriješiti problem enigme ljudske egzistencije. Kršćanski 
humanizam nudi model konvergentnosti teologije i filozofije. On je stoga u sebi sinteza razuma i vjere, a kao takav posreduje jasna načela i kriterije prosudbe, baš kao što potiče i kulturu konačne, apsolutne istine, u kojoj se može ostvariti dijalog različitih potraga za istinom.

\section{Literatura:}

Ančić, Nediljko Ante (2008). Neka promišljanja o enciklici Fides et ratio prigodom desete obljetnice. Bogoslovska smotra, 78 (4), 747-760.

AP. Aeterni patris. U: Lav XIII., Aeterni patris: Encyclical of pope Leo XIII on the restoration of christian philosophy. URL: http://www.vatican.va/holy_father/leo_xiii/encyclicals/ documents/hf_l-xiii_enc_04081879_aeterni-patris_en.html (01.09.2017)

Balthasar, Hans Urs von (2012). Cjelina u odlomku. Zagreb: Kršćanska sadašnjost.

Dadić, Borislav (2000). Metafizika u enciklici Fides et ratio. Obnovljeni život, 55 (3), 389397.

Despot, Branko (2008). Vjera i filozofija (s ovu i s onu stranu uma). Bogoslovska smotra, 78 (4), 741-746.

Devčić, Ivan (2000). Veritatis splendor i Fides et ratio — dva krila jednog triptiha. Obnovljeni život, 55 (1), 91-100.

Fabro, Cornelio (1988). L'enigma Rosmini: Appunti d'archivio per la storia dei tre Processi (1849, 1850-1854, 1876-1887). Napoli: Esi.

Fabro, Cornelio (2004). Riflessioni sulla libertà. Roma: EDIVI.

FR. Fides et ratio. U: Ivan Pavao II., Fides et ratio: Vjera i razum: enciklika svim biskupima Katoličke crkve o odnosu vjere i razuma. Zagreb: Kršćanska sadašnjost, 2004.

Heidegger, Martin (1988). Bitak i vrijeme. Zagreb: Naprijed.

Hünermann, Peter (2008). Fides et ratio — nekoć i sad (?!). Bogoslovska smotra, 78 (4), 721-740.

Ivančić, Tomislav (2008). Fides et ratio nakon deset godina. Bogoslovska smotra, 78 (4), 761-767.

Kešina, Ivan (2013). Značaj enciklike Aeterni Patris za obnovu tomističke filozofije u 19. i 20. stoljeću. Obnovljeni život, 56 (2), 219-228.

Kierkegaard, Søren (2000). Strah i drhtanje. Split: Verbum.

Macan, Ivan (2000). Filozofija u crkvenim dokumentima. Obnovljeni život, 55 (1), 25-38.

Maritain, Jacques (1978). Sulla filosofia cristiana. Milano: Vita e pensiero.

Maritain, Jacques (1981). Il contadino della Garonna. Brescia: Morcelliana.

Maritain, Jacques (1995). Tri reformatora. Split: Laus.

Merleau-Ponty, Maurice (1978). Fenomenologija percepcije. Sarajevo: Veselin Masleša.

Otto, Rudolf (2006). Sveto: o iracionalnom u ideji božanskoga i njezinu odnosu spram racionalnoga. Zagreb: Scarabeus.

Rahner, Karl (1963). Theological Investigations, II. London: Heilcon Press.

Rahner, Karl (2007). Temelji kršćanske vjere: Uvod u pojam kršćanstva. Rijeka: Ex libris.

Ratzinger, Joseph (2004). Vjera - istina — tolerancija. Zagreb: Kršćanska sadašnjost.

Rossi, Philip (2000). After Fides et ratio: New Models for a New Millennium. Philosophy and Theology, 12 (2), 419-429. DOI: 10.5840/philtheol200012225 (01.09.2017.)

Seckler, Max (2005). Razum i vjera, filozofija i teologija. U: Nediljko Ante Ančić i Nikola Bižaca (ur.), Govor o Bogu jučer i danas: Zbornik radova međunarodnoga znanstvenog skupa (str. 81-100). Split: Crkva u svijetu. 
The Convergence of Faith and Reason in Light of a Hetero-Affirmation of the Encyclical Fides et Ratio

\section{Marko Vučetić*}

\section{Summary}

The article discusses the philosophical aspect of building Christian humanism contained in the Encyclical Fides et Ratio. In analyzing the reciprocal autonomous relationship between philosophy and theology, a platform has been created for the synthesis of faith and reason, not however to be seen in light of hermeticism, but in keeping with the laws of authenticity. An authentic philosophy cannot become a theology, similarly an authentic theology cannot become a philosophy. The principle of hetero-affirmation embodies the synthesis of faith and reason in such a way that the truth is liberated from a formalistic and alienated form of reality. An existentially relevant truth is one that does not exclude, one that has powerful integrative mechanisms, and that contributes to the meaningfulness of human life.

Key words: philosophy, theology, faith, reason, existence

* Marko Vučetić, Ph.D., Assistant Professor, University of Zadar, Philosophy Department. Address: Obala kralja Petra Krešimira IV.br.2,23000 Zadar, Croatia. E-mail: mvucetic@unizd.hr 